\title{
The Teaching of Mathematics in the Greek Military Academy (1834-1854)
}

\author{
Andreas Kastanis \\ Department of Military Sciences, Greek Military Academy (Evelpidon School), Athens, Greece \\ Email address: \\ Andreas_Kastanis@yahoo.gr
}

To cite this article:

Andreas Kastanis. The Teaching of Mathematics in the Greek Military Academy (1834-1854). International Journal of Vocational Education and Training Research. Vol. 7, No. 1, 2021, pp. 21-29. doi: 10.11648/j.ijvetr.20210701.14

Received: April 13, 2021; Accepted: April 26, 2021; Published: May 8, 2021

\begin{abstract}
The educational policy of King Otto, advised during his first years in Greece by Bavarian experts, caused considerable turmoil. Two organizational models were in use, the German one for the University and the French one for the Evelpidon Military School (Greek military academy) and the School of Technology (a forerunner of the Polytechnical School). France's École Polytechnique remained nonetheless the basic educational model for the Greek military academy. The new educational policy created a number of scientific obstacles that did not favor the flourishing of mathematical education. The length of study at the Greek military academy Greek military academy increased to eight years and new mathematical courses were added to its program, so that its graduates would be able to take upper level technical courses. Bourdon's Arithmetic, Legendre's Geometry and Trigonometry, Francoeur's Algebra, Monge's Descriptive Geometry, Differential and Integral Calculus, etc, formed the basis of the cadets' mathematical education. Mathematics was included in the subject matter so that the graduates would be in a position to understand the theoretical basis of the technology employed, as well as, crucially, to help the cadets understand upper-level technical courses. Another reason for the teaching of Mathematics was the materialization of the political goal set by the governments of the Ottonian period, that is access to Europe's technological achievements. The introduction of additional and more difficult upper-level technical courses required the introduction of new mathematical courses to the program.
\end{abstract}

Keywords: Military Academies, Ecole Polytechnique, Legendre, Bourdon, Monge, Greece

\section{Introduction}

The Greek military academy (Evelpidon Military School -

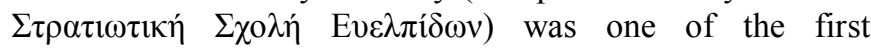
institutions of tertiary education in liberated Greece. Mathematics courses formed the greater percentage of the Evelpidon Military School curriculum. The School was financed by France and organized by French officers, who used as their organizational model France's École Polytechnique [16]. Teaching needs were met by translated French mathematical textbooks, which were necessary for taking upper-level technical courses. Bourdon's Algebra [6] and Arithmetic [24], Legendre's Geometry [24], Monge's Descriptive Geometry [27], and Mathematical Mechanics formed the basis of the cadets' mathematical education ${ }^{1}$.

In order to understand the role of the teaching of

1 For more on the first period of operation of the Evelpidon see: [19].
Mathematics at the Greek military academy (Evelpidon Military School) during the period under investigation it is necessary to answer the following questions: What was the significance of the teaching of Mathematics at the Evelpidon Military School? Which were the scientific obstacles for mathematical courses? Which were the organizational goals of tertiary technical education in Greece? What kind of educational policy was designed by the Bavarians? Was there any continuity between their choices and the Kapodistrian period (1829-1834)? The answers to these questions will allow for an understanding of the significance of the teaching of mathematics at the Greek military academy. The present study investigates the period from the introduction of the new Evelpidon Military School program by the Bavarians (1834), which altered the mathematics curriculum (new courses were added), to the succession of Higher Mathematics Professor Dimitrios Despotopoulos by Michael Sofianos (1854), who gave a new direction to the School's mathematical education 
thanks to the publication of a complete series of mathematical texts.

The assassination of Governor Ioannis Kapodistrias and the arrival of King Otto ${ }^{2}$ brought once again some turmoil in the area of education, but without breaking its continuity. The vocational orientation of education, a primary goal of Kapodistrias, was now lost. The educational policy of the Bavarians $^{3}$ [36] gave a new direction to education. The Regency postulated as primary social necessity solely the formation of a European state (Europe having turned into a model for Greece), without taking into account at all Greece's broader professional and technical needs (technical education, linking education to economy, etc). The leading political and social goals were the unification and homogenization of the state.

\section{The Bavarian Educational Policy}

The Bavarian educational policy is marked by three characteristics. First, a strong theoretical leaning toward the Classics, favored by Greek society (and the Church); second, the centralized structure of the educational system; and third, free education [36]. These characteristics were conducive to the moderation of the strong parochialism that prevailed in the provinces of the new state, resulting thus into its unification, the reconnection of Neohellenes to their ancestors, the installment in Greeks, through education, of a novel national identity, and, finally, the smooth expansion of the school network into local societies through free education.

Tertiary education would aim more toward the Classics, for it would share the same goals with secondary education and, further, Greeks would aim toward the shaping of a novel and stronger national identity ${ }^{4}$. In practice, the main goal of tertiary education would be the creation of top state executives, with no interest in broader social needs (for example there was no development of agricultural science or maritime science in a primarily agricultural and maritime state), hindering therefore the spreading of the teaching of mathematics.

There were two models for the development of tertiary education, the German $\operatorname{model}^{5}$ [22] and the French model. In

2 The free Greek state attained its definite legal foundation in 1832. England, Russia, and France, acting in the name of the Greek state offered the throne of the newly founded state to seventeen-year-old Otto, second son of the philhellene king of Bavaria Ludwig A'. Otto's father appointed three regents to serve until Otto would reach adulthood.

3 It must be noted that the Bavarian state and its bureaucracy were influenced by Napoleon's policy. The Bavarian higher officers who came to Greece had been raised with Napoleon's views about a strong, centralized, and liberal state. These views penetrated Greece not only via the ideas of the Enlightenment but also through the Bavarians themselves, who, despite their authoritativeness, introduced many Napoleontian principles to the institutions of the newly founded Greek state 4 A helleno-christian identity was shaped in the 1850's thanks to Zampelios and Paparrigopoulos.

5 The national goals of the Greeks were in many ways similar to those of the Germans, they were in other words of a territorial, irredentist, unifying, and, mainly, visionary nature. The Prussian (German-to-be) University in particular was an institution foreseeing the unification of Germany. In contrast to the French the first one, the student body consisted of the offspring of the noble classes, who were interested not in employment prospects but in personal development. In the second model, the character of tertiary education changed after the French Revolution: the old upper class schools gave way to institutes allowing their graduates the possibility of a professional career [22]. In Greece the main model for the organizing and functioning of education was the German one (university, high school, public school), with French technical schools (tertiary or not) being the model for technical education (Greek military academy and School of Technology).

The arrival of the Bavarians in Greece found the Central Military School (the Greek military academy of the Kapodistrian period) in operation. Despite the dismantling of all military corps, units, and services, the Evelpidon Military School not only was retained but it continued to operate for about another year under the same organizational mode and with the same learning objectives as during the Kapodistrian period. The decision by the Bavarians to continue the operation of the War School - the only military institution not to be dismantled - shows their intent to maintain the continuity of the learning and operating aspects of the education provided by the school (and, by extension, of the mathematical education provided as well [21].

The Greek military academy, as organized by the French in 1829 , provided advanced technical education. In his reply to Jean-Henry-Pierre-Augustin Pauzié (French officer and organizer of the Evelpidon Military School), Kapodistrias, accepting his proposal for the formation of a Military School, refers to a "Polytechnic Military School" [16]. Also, in a letter to Colonel Heideck ${ }^{6}$, Kapodistrias writes about the cadets: "Your young architects have been proven most worthy of the school you established, and having tackled the task they work most productively and gratify me" [13].

The nature of technical education offered by the School was retained under the restructuring brought about by the Bavarians in 1834. In 1837 (the decree was published on December 31, 1836) the School of Technology was established [13], its purpose being the training of top masters (protomastores) in Architecture [26]. Both these schools were modeled after French educational institutions. The Evelpidon Military School was modeled after the École Polytechnique [19] and the School of Technology was modeled after the École des Arts et Metiers of Paris [7]. These educational institutions used translations of French mathematical books, mainly as modified after the French Revolution of 1789, in order to be more accessible to technicians. Emphasis was placed mostly on applications rather than the teaching of pure

educational system, neo-humanism was a crucial element of the German one. 6 Karl von Heideck (1788-1861). Bavarian general. He studied in Munich and served in the Bavarian army. He fought for Austria as a first lieutenant and, later on, in 1813, with the French army against Spain. He came to Greece during the Greek Revolution and took part in many battles. In 1828 he was appointed by Kapodistrias administrator of Nafplion. In August 1829 he returned to Bavaria, but again came back to Greece as a member of Otto's Regency. He stayed in Greece until 1835. He wrote a memoir about the Greek Revolution, published in the magazine Armonia. 
mathematics. Priority was given to a new view of geometry, specifically of three-dimensional space, concerned with transformations associated with motions [9]. The plan of the government was for the Evelpidon Military School to primarily train public sector engineers who would undertake state technical works (public buildings, roads, bridges, etc) or the management of various public technical departments (such as mint, salt flats, etc), and to secondarily train technical officers in charge of the fortification of the country or large-scale repairs of technical military material (mainly canons).

\section{The Social Prospects of the Teaching of Mathematics}

Mathematics was the most important course, preparing the cadets for the understanding of difficult technical courses [19]. Its teaching provided all the knowledge needed for the understanding of upper-level technical courses and the theoreticalization of crafts and techniques. At the same time, Mathematics provided the cadets with a common language and knowledge that would lead them to the development of uniformity and the attainment of precision during the execution of orders. This course was not an internal educational matter, but it was set to help the graduates relate to other social groups (like top masters or simple craftsmen) and material objects (which were tools of production) from an expected leading position [1 and 2]; that is, to be in charge of the production chain of public works (Engineering officers) or Armory tasks ${ }^{7}$ (Artillery officers). The use of Mathematics provided the option of logical analysis of a task before its execution, leading therefore to the theoreticalization of the construction process [Oraiopoulos, 1998, 49]. Mathematics formed the common language that allowed for the organizing of an academic technical education. According to Thiersch critical thinking ability must be developed mainly through the precise study of Mathematics [Thiersch, 1972, 2: 115].

It seems that the use of Mathematics in the process of Artillery firings was not a basic goal at Greek military academy. Ballistic Science, while considerably developed, had not yet been applied toward practical problem solving ${ }^{8}$. The main problem facing the gunners was the creation of stable conditions of interior ballistics ${ }^{9}$, deferring thus to the

7 Military workshop in charge of extensive repairs of canons and other guns of the era.

8 Three phases in the development of Ballistics may be traced. The first phase was formulated by Tartaglia, who introduced the theory that the motion of the missile was a combination of violent thrust and free fall: the first part of the motion was straight, following the line of firing, the second one formed a small arc combining the violent thrust and the weight, and the third part was a vertical free fall. The second phase was formulated by Galileo, who introduced the theory of the parabolic orbit of the missile. The third phase was formulated by Euler, who did take into account air resistance during the missile's motion in the atmosphere.

9 Interior ballistics examines all the factors affecting the missile's motion inside the cannon's tube (and before the missile exits through the cannon's muzzle). engineers. All together, twenty five factors (of interior ballistics) were found to affect the success of firing; these factors varied from the eccentricity of the canon tube to the variable projectile weight [1].

The relation of the totality of the Greek officers corps to Mathematics is an interesting issue. Greek military academy graduates formed a small percentage of the entire corps. With an "About Officers' Promotions" decree of October 3, 1834, the Government established an examination system in front of a committee. Evelpidon Military School graduates were exempt from these examinations. In order for a sergeantmajor to be promoted to the rank of adjutant he had to be tested on the four arithmetical operations; and Infantry adjutants had to be tested on the four operations as well as the first chapters of Geometry (length measurement) in order to be promoted to second lieutenants) [8].

The interest of the officer corps - as expressed via private military journals - in Mathematics, more specifically in Geometry, was great. In the military journal "Military Herald" (Stratiotikos Aggelos) its editor H. Byzantios published a series of six Elementary Geometry lessons [38]. The goal was for Mathematics to be mastered by all officers - that is to extend its teaching to Infantry and Cavalry officers - in order to develop uniformity and precision [1], to strengthen thought justification, to foster a common corps spirit through a common language, and, finally, to communicate to all officers the technological achievements of the West. Concerning Mathematics, the views of the journal "Military Herald" were identical to those of the French organizers of the Evelpidon Military School. Mathematical thinking was more and more connected to military thinking [19].

At the same time, the course of Mathematics functioned as an instrument of progressive democratization [1]. It was a faceless process which, in connection to the examinations, strengthened meritocracy and equal opportunity among the cadets. It is not a coincidence that during the Revolution of September 3, 1843 (demanding democratization and a constitution) the percentage of participation of Evelpidon Military graduates reached $20 \%$ [18], a percentage especially high in comparison to that of the entire officers corps.

\section{Obstacles to the Spreading of Mathematical Education}

On the other hand, the absence of technical schools was a scientific obstacle to the spreading of mathematical education. The craftsmen active in Greek territories were members of various trade unions, which did not come into contact with technical education in Greece. The most probable reason is that they had their own apprenticeship (practical training), which was recognized by the state ${ }^{10}[12]$, so they were concerned that collaboration with various technical schools would contribute to the loss of their

10 The supervision of an architect engineer was not required for the erection of high-rises prior to 1930; even after 1930, buildings up to two floors high were allowed to be built by amateur engineers. 
privileged position. In 1837, for example, the architect (top master of the builders union) paid the highest tax to the Greek state, which means that he was paid more than any professional (including doctors, lawyers, etc) [30].

The trade unions were in close contact with the Church, to the point that in Ioannina they enforced the replacement of several bishops [31]. The establishment of technical schools was probably opposed by the Church itself, in order to support the trade unions. It is clear that the lack of theoreticalization of the various practices of Greek craftsmen led to an inability to promote upper technical courses and therefore to all the conditions essential for the formation of a scientific obstacle to the spreading of Greek mathematical culture. Any theoreticalization of crafts would open the profession to the society and so the trade union would lose its leading role; and this situation was not conducive to the establishment of technical schools ${ }^{11}$. One of the first training manuals of Architecture [Hors, 1887-1888] at the Greek Military Academy itself lacks any reference to the structures related to traditional Greek architecture (churches, houses, etc); instead, it describes mathematicalized and theoreticalized construction techniques (mainly French) through buildings of European architecture.

Another scientific obstacle to the spreading of the course of Mathematics was the merchant character of the economy ${ }^{12}$ [36], which did not favor the development of productive and industrial activities. The lack of such activities was not leaving much room for the development of technical education of any level in Greece. In general, it is noticed that technical education was confounded by a very narrow governmental policy: there was no provision for the education of technical scientists in areas in which the state had no interest; and there was no provision for technical scientists who would offer their services to private citizens. Technical education, primarily at Evelpidon Military School and secondarily at the Technology School, was probably an exception in the entire field of education.

\section{Mathematical Courses}

The entire process of learning at the Greek Military Academy, after the introduction of the new program in 1834, was divided into eight grades. The division of learning into grades, and more generally its administrative form, was based on Bavarian models ${ }^{13}$ [32]. The Bavarian influence at the Evelpidon Military School appears to be limited to organizational and functional issues ${ }^{14}$. The first four grades were preparatory, enabling the cadet to advance to the upper

11 The field of technical construction was fragmented in Greece. The army's technical corps (Engineering, Artillery) never collaborated with trade unions, but created their own technicians instead.

12 Tsoukalas mentions that the merchant character of the economy did not favor the development of technical education and, consequently, the development of Mathematics.

13 Ragavis describes the division into classes in the Bavarian Military School of Munich and its similarities to the corresponding Greek School of Evelpidon.

14 Throughout the Greek Army a system combining French and Bavarian rules was dominant. grades. Students in these grades received the standard education, analogous to that of high school students of same age (secondary education), but mathematically strengthened. The mathematics subject matter in the preparatory grades did include:

Table 1. The program of mathematical course in the preparatory grades.

\begin{tabular}{lll}
\hline $2^{\text {nd }} \mathbf{G r a d e}^{15}:$ & $\mathbf{3}^{\text {rd }}$ Grade & $\mathbf{4}^{\text {th }}$ Grade \\
\hline $\begin{array}{l}\text { Continuation of } \\
\text { Arithmetic through } \\
\text { ratios }\end{array}$ & & \\
Algebra, equations of & $\begin{array}{l}\text { Algebra - introduction to } \\
\text { series, logarithms, higher }\end{array}$ & $\begin{array}{l}\text { Mathematics, Theory } \\
\text { of Functions }\end{array}$ \\
$1^{\text {st }}$ and $2^{\text {nd }}$ degree & degree equations ${ }^{16}$ & Mathematics, \\
Straight Line & Length Measurement and & Solid Geometry and \\
Geometry & Plane Geometry & Plane Trigonometry \\
\hline
\end{tabular}

Later, in 1836, the first preparatory grade was eliminated. In the related decree it is mentioned that public schools were now better organized, so that a reduction in the number of preparatory grades was possible [8]; in fact, the real reason had probably more to do with the financial difficulties of the Greek state. In 1839 the second preparatory grade was also eliminated, so that the years of study were reduced to six (two preparatory grades and four regular ones) [8].

After the elimination of the two preparatory grades, the numbering of classes was done in a manner similar to that of the Kapodistrian period [19]. The first scholastic year class was named $3^{\text {rd }}$ section of the $\Delta^{\prime}$ class and the second scholastic year class was named $2^{\text {nd }}$ section of the $\Delta^{\prime}$ class. Starting with the $3^{\text {rd }}$ scholastic year, first non-preparatory one, the naming was based on Hellenic numerals, that is $\Delta^{\prime}$ class through the last Z' class.

Following the elimination of the two preparatory classes, the Educational Council ${ }^{17}$ [19]. conferred to decide the distribution of courses to the remaining six classes. First, new prerequisites were set: in mathematics the cadets ought to know the four operations of ordinary fractions, decimals, and mixed numbers, the theory of the Largest Common Divisor, and the conversion of ordinary fractions to decimals. Next, a new program was issued, in which mathematics courses per class were as follows [39]:

Table 2. The program of mathematical course in the First Scholastic Year of $\Delta$ 'class.

\begin{tabular}{ll}
\hline $\begin{array}{l}\text { First Scholastic Year }\left(3^{\text {rd }} \text { section }\right. \\
\left.\text { of } \Delta^{\prime} \text { class }\right)\end{array}$ & $\begin{array}{l}\text { Second Scholastic Year }\left(2^{\text {nd }}\right. \\
\left.\text { section of } \Delta^{\prime} \text { class }\right)\end{array}$ \\
\hline Arithmetic & \\
Algebra & Algebra \\
Geometry & Geometry \\
\hline
\end{tabular}

15 The first grade did not include the teaching of any Mathematics. 16 Equations of $3^{\text {rd }}, 4^{\text {th }}$, etc degrees.

17 The President of the Student Council was Engineering major Dimitrios Stavridis. The members of the Student Council were: Engineering sublieutenant N. Misoudakis, Artillery sublieutenant Efstathios Tomaropoulos, Engineering adjutant N. Manou, and the $1^{\text {st }}$ order professor Dimitrios Despotopoulos. 
The regular ranks remained four according to the following Mathematics curriculum:

Table 3. The program of mathematical course in the third, fourth and fifth Scholastic Years.

\begin{tabular}{|c|c|c|}
\hline $\begin{array}{l}\text { Third Scholastic Year } \\
\left(\Delta^{\prime} \text { class] }\right.\end{array}$ & $\begin{array}{l}\text { Fourth Scholastic } \\
\text { Year (E' class) }\end{array}$ & $\begin{array}{l}\text { Fifth Scholastic Year } \\
\left(\Sigma T^{\prime} \text { class }\right)^{18}[48]\end{array}$ \\
\hline $\begin{array}{l}\text { Algebra } \\
\text { Trigonometry } \\
\text { Analytic Geometry }\end{array}$ & Descriptive Geometry & $\begin{array}{l}\text { Analytic Geometry } \\
\text { Differential and } \\
\text { Integral Calculus }\end{array}$ \\
\hline
\end{tabular}

The new subject matter, as presented in the Program of 1834, increased substantially the teaching hours and the mathematical subjects in relation to the Kapodistrian period. Two mathematics professors were hired to meet these demands, one to teach upper-level courses and one to teach lower level courses. The two categories corresponded to teaching regular classes (upper-level mathematics) and preparatory classes (lower-level mathematics). Upper-level mathematics included Algebra, Trigonometry, Analytic Geometry, Differential and Integral Calculus, and were allotted 5 hours weekly for the $3^{\text {rd }}$ scholastic year ( $\Delta^{\prime}$ class) and $31 / 2$ hours for the $\Sigma \mathrm{T}^{\prime}$ class. Lower level mathematics consisted of Arithmetic, Algebra, and Geometry, and were allotted 5 hours weekly for the $3^{\text {rd }}$ section of $\Delta^{\prime}$ class $\left(1^{\text {st }}\right.$ Scholastic Year) and 6 hours for the $2^{\text {nd }}$ section of $\Delta^{\prime}$ class ( $2^{\text {nd }}$ Scholastic Year)) [39]. In essence, lower-level courses belonged to secondary education subject matter and upperlevel courses to that of tertiary education. Descriptive Geometry (E' class) was not part of upper-level mathematics, but was a special course, taught initially by the Architecture Professor [40]. Unlike that of the Kapodistrian period, the Program of 1834 does not refer to any textbooks on which teaching ought to be based.

The highest paid professor was the one of Upper-Level Mathematics, receiving 300 drachmas per month and having the rank of $1^{\text {st }}$ Order Professor. The Lower-Level Mathematics professor was paid 170 drachmas per month and had the rank of $2^{\text {nd }}$ Order Professor [40].

The cadets used as auxiliary textbooks mathematical books by various authors or tetradia (this is how they called lithographic books). Teaching was auditory; the cadets copied lessons in their spare time from the notes (tetradio) ${ }^{19}$ of the professor (Despotopoulos), which was a compilation from various authors [41]. After 1854, following the replacement of Despotopoulos by Sofianos (a graduate of the Greek military academy), the School published a complete series of mathematical books.

As during the Kapodistrian period (1829 - 1834), the entire program of the Greek military academy was influenced by that of the École Polytechnique [19].

In Bavaria, even through the beginnings of the 1860's, the equivalent of Greek military academy lacked considerably in

18 The $6^{\text {th }}$ scholastic year included only upper technical courses and no Mathematics.

19 Despotopoulos reported to the Evelpidon the publication of tetradia misplaced in time by the cadets. To this day no such tetradio has been located. comparison as far as the teaching of Mathematics was concerned. The program of study at the Bavarian military school consisted of: common fractions, decimal numbers, method of three, interest, mental calculations (First Class); system of weights and measures, fractions, decimal numbers, mental calculations (Second Class); algebra, geometry (Third Class). In general, technical courses were completely absent [4]. In Munich the first Polytechnical School was established only in 1868 [33, 28].

It is plausible that this situation led the Regency to decide to continue using the same (French) model as that of the Kapodistrian period; further, it was decided for the Greek military academy program to consist of almost the same courses as that of the École Polytechnique, and so the levels of studies were comparable as well. In effect, the entire Evelpidon Military School program, and the teaching of Mathematics in particular, constituted an imported educational model aimed at mastery of imported technology rather than development of national or military technology.

The Student Council believed that the course of Arithmetic belonged to the preparatory grades and decided therefore that it would be taught only at the $3^{\text {rd }}$ section of $\Delta^{\prime}$ class (first scholastic year). The subject matter was: divisibility of numbers, determination of divisors, prime and composite numbers, periodic decimal fractions, reduction of ordinary decimal fractions to ordinary ones, theory of ratios and its application to various commerce techniques, extraction of square root [39]. It should be noted that the subject matter was almost the same as that of the preceding Kapodistrian period, except that it did not include progressions and logarithms.

The textbook used at the Evelpidon Military School was Bourdon's Arithmetic [41], taught by second lieutenant Anargyros Anagnostou. This is corroborated by the fact that the subject matter and this book's second part were identical; the introductory part, which was not included in the teaching of Arithmetic, corresponded to subject matter incoming cadets were expected to know already.

Initially the translation used for the Arithmetic textbook was that of Karantinos, to be followed later on [42] by that of Georgios Kondis (1812-1863) [23], a student of Karantinos and principal of the Nafplion Gymnasium [20], which was apparently taught through the end of the Ottonian period [43]. Both the subject matter of Arithmetic and the choice of textbook demonstrate continuity with the Kapodistrian period.

Judging from a question given at a mathematics examination $^{20}$ during the promotion examinations of 1848 , it seems that emphasis was placed on applications of Arithmetic to commerce. The first question was theoretical, specifically "what is discount", and the second concerned the following problem: find the present value of a note issued at 6,575 drachmas which must be paid after 19 months and 20 days, assuming a monthly interest rate of $2 \%$ [44].

Opting for the solution of an exercise as an examination

20 The examination included arithmetic, geometry, and algebra. 
question might have been a novelty for the educational system of that period: almost no textbook from that era contained exercises. The solution of exercises during examinations allows us to conclude that the corresponding training was provided during lectures: perhaps the cadets practiced solving exercises in class. At the same time, the effort to demonstrate the practical nature of Mathematics through problem solving is evident.

The Student Council decided for Geometry to be taught only in the first two preparatory grades. First the $3^{\text {rd }}$ section of the $\Delta^{\prime}$ class would cover the first four chapters (books) of Legendre's Geometry (Plane Geometry), and then the $2^{\text {nd }}$ section of the $\Delta^{\prime}$ ' class would cover the last four books (Solid Geometry) [39]. The choice of Legendre's Geometry [16 and 14] as a textbook as well as the selection of the subject matter was the same as that of the Kapodistrian period.

The questions in the examinations that have been located were exercises: determine the side of the regular hexagon [45]; show that the lateral surface of a frustum is equal to the product of its edge times the average of its base circumferences [46].

Legendre's Geometry dominated Greece's mathematical learning throughout the $19^{\text {th }}$ century. It was translated many times by various authors. It was used as a textbook in Greek high schools [34], but was also included in 1837 in the University program.

The subject matter for Algebra was distributed into three grades (two preparatory, one regular). The Student Council decided that the following chapters should be taught:

a) First preparatory grade. The four operations on algebraic monomials and polynomials; indeterminate first-degree equations in one or several unknowns; the theory of negative quantities and the solution of indeterminate first-degree equations; the calculation of roots of monomials; the theory of negative and rational exponents; the extraction of the square root of a polynomial.

b) Second preparatory grade. The solution of seconddegree equations; progressions and logarithms; construction and use of logarithmic tables; applications of logarithms to compound discount, interest, and annual annuity; permutations, arrangements, combinations; Newton's binomial with its applications to the extraction of roots of any order of a number; the development of analytical expressions into series.

c) First regular class. Theory of indeterminate coefficients and their application to series; theory of logarithmic and exponential series; determination of the sum of equal powers of terms of an arithmetic progression and application to the determination of the number of cannon balls packed into a triangular or square pyramid or a truncated prism; continued fractions; the theory of equations of higher degree in brief; the general solution of $3^{\text {rd }}$ and $4^{\text {th }}$ degree equations [39].

The Algebra textbook used during the first years of the Ottonian period is not known. Once Anargyros Anagnostou (1812-1870) [18] began to teach lower level mathematics he produced a lithographic Algebra textbook titled Algebra Lessons $^{21}$ [2], based on Francoeur's Algebra [41] (possibly the Algebra included in Cours complet de mathématiques pures ${ }^{22}$ ). It is very likely that during the initial interval, prior to Anagnostou's hiring, both lower and higher-level Algebra was taught by the Evelpidon Militray Mathematics professor Dimitrios Despotopoulos, whose teaching was based on notes kept by the cadets. After Anagnostou's hiring Despotopoulos went on with the teaching of upper level Algebra. The fact that Bourdon's Algebra was not published could have been one of the main reasons for choosing that of Francoeur as a textbook. Either way, the teaching of Algebra followed the French model.

In higher level Algebra examinations found, the questions were exercises concerned with the solution of third-degree equations, for example [47] $x^{\wedge} 3+2 x^{\wedge} 2-3 x+6=0$.

The subject matter included planar and spherical Trigonometry. This course was part of higher level Mathematics and was taught by Despotopoulos. The textbook used is not known, but it could have been Legendre's Trigonometry, translated by Karantinos and acquired by the Greek military academy during the previous (Kapodistrian) period. The examination question in Spherical Trigonometry that was located concerned the solution of an exercise, adjusted to Greek geography at that: given the longitudes and latitudes of two points on the globe determine the distance between them; that is, determine the distance between Athens (North Latitude $37^{\circ} 57^{\prime}$, Longitude $21^{\circ} 45^{\prime}$ ) and Nafplion (North Lattitude $37^{\circ} 35^{\prime}$, Longitude $20^{\circ} 27^{\prime}$ ') [48].

Third scholastic year. The subject matter included: two dimensions; equations of circle and line, and problems related to them; geometrical loci and equations of ellipse, parabola, and hyperbola; the general equation of seconddegree curves as derived from the intersection of an upright cone and a plane; in brief, the method of tangents; conjugate diameters.

Fifth scholastic year ( 5 hours weekly). Analytic Geometry in three dimensions; equations of line, plane, cone, cylinder, sphere; surfaces of revolution. The textbook used is not known $^{23}$.

Applications to the theory of minimum and maximum; meaning of $0 / 0$ and infinity over infinity in the theory of evolutes; theory of tangents; area under curves; area of surfaces of revolution. Even though it looked like one course, the cadets took separate examinations in Differential Calculus and Integral Calculus. The two examinations took place on the same day, but the cadets were given separate exam books and separate questions. A sample exercise in

21 This book was found in GAK. The research conducted located only the second and fourth editions; the first and third editions were not located. The December 2004 Metsovion Polytechnic data base titled Greek Scientific and Technical Bibliography (1830-1940) corroborates the results of our research.

22 The information about Anargyros Anagnostou's reliance on Francoeur's Algebra comes from GAK. What exactly Anagnostou had in mind is not clear. The answer to this question will probably be the topic of future research.

23 The Analytic Geometry examinations that were found belong to Sofianos' period (after 1854). 
Integral Calculus [49] was: determine the volume of an ellipsoid with revolution axis equal to 18 meters and perpendicular axis equal to 10 meters.

The subject matter included cross sections and applications of Projective Geometry to Sciagraphy (Shadow Theory) and to Scenography (Theory of Perspective). Further, the practical training included measurement of buildings and machines, teaching of the main wooden frames and wood sections, and construction of the five canonical orders, that is Tuscan, Doric, Ionian, Corinthian, and Roman (or Composite). Descriptive Geometry was taught for $1 \frac{1}{2}$ hours per week, and its applications for 2 hours per week [39]. The instructor was lieutenant colonel Stavridis, who based his teaching on the tradition of Monge's Descriptive Geometry ${ }^{24}$, which was also used for the lectures on Sciagraphy and Scenography. The cadets kept notes during lectures [19]. Professor Stavridis' teaching of Monge's Descriptive Geometry was in continuity with its use during the Kapodistrian period.

The subject matter, compared to that of the Kapodistrian period, indicates that two new courses were added, Integral and Differential Calculus and Analytic Geometry. These additions came together with the introduction of many new technical courses. The goal of the teaching of Mathematics appears to remain the same, that is the understanding of upper level technical courses.

A comparison of the two programs, that of the Greek military academy and that of the École Polytechnique, indicates that Integral and Differential Calculus, Analytic Geometry, and Descriptive Geometry were purely tertiary level courses. If such a comparison is extended to technical courses, then the education offered at the Evelpidon Military School may be classified as tertiary level education.

Further, the course distribution of the whole program shows that the completion of the mathematical material was followed by the teaching of upper level technical courses such as Architecture, Fortification, Geodesics, etc. These courses were the ones on the rise, and their teaching required the mastering of advanced mathematical concepts. Special emphasis was placed on the teaching of applied mathematics courses such as Descriptive Geometry.

Te Evelpidon Military School program was oriented toward providing all the required knowledge for its graduates to join the technical corps of the era (Engineering and Artillery). In general, the subject matter was geared toward providing general upper-level technical knowledge without specialization, just as at the École Polytechnique. Absent from Greece were the respective Application Schools (Écoles d'Application) of France. The subject matter was more appropriate for the training of individuals suitable to be in charge of Public Works and higher State Offices (such as Mint, Salt Flats, etc) than for the training of army officers.

Throughout the Ottonian period Greek military academy graduates were sent abroad, mainly France and

24 Monge's Descriptive Geometry was never translated into Greek. For more on Descriptive Geometry [15].
Germany, to continue their studies. The focus of this postgraduate training was the continuation of technical education. Greek interest was centered almost exclusively around graduate studies at the École Polytechnique, the School of Applied Engineering and Artillery at Metz, other French non-military technical schools, and German universities for the acquisition of special physics and mathematics knowledge ${ }^{25}$.

A first assessment of studies indicates that the French did recognize the Evelpidon Military School (Greek military academy) diploma; Greek military academy graduates were accepted at the School of Applied Engineering and Artillery at Metz, where those graduates of the École Polytechnique set for a career in the Corps of Artillery or Engineering continued their studies [4]. Throughout the Ottonian period the Greek military academy functioned as a School of Engineering rather than a military academy. This view is confirmed by the Evelpidon Military School director, colonel of Engineering Corps Vassilios Petmezas, in a report to King George A' regarding the need for a radical transformation of the Greek military academy [37]. Although navy officers also graduated from the Greek military academy, there was absolutely no provision for any teaching related to nautical education.

\section{Conclusions}

The decision of the Bavarians in favor of the continuing function of the Military School for about one year under the same program that was in effect during the Kapodistrian period and also in favor, after its restructuring, of keeping the same textbooks and of introducing more courses influenced by the French model demonstrates the learning and operational homogenization of Greek mathematical teaching at the Evelpidon Military School. Sticking to the learning and organizational model of the École Polytechnique was a further basic factor of learning and operational homogenization of mathematical teaching at the Evelpidon Military School. The introduction of additional and more difficult upper-level technical courses required the introduction of new mathematical courses to the program.

Mathematics was included in the subject matter so that the graduates would be in a position to understand the theoretical basis of the technology employed, as well as, crucially, to help the cadets understand upper level technical courses. Another reason for the teaching of Mathematics was the materialization of the political goal set by the governments of the Ottonian period, that is access to Europe's technological achievements. At the same time, it equipped the army with a common language needed for fostering a common spirit that would assist the Evelpidon Military School graduates toward a comfortable leadership role in their dealings with other social groups and various material objects (such as machines, technical works, etc).

25 For more information on Officers that studied or continued their studies abroad, see: [18]. 
At the period under investigation, the course of mathematics was an emulation of French models free of any discernible intervention and aimed at the understanding of high-level technical concepts and applications. The Greek state appeared to have accepted this situation and to be concerned only about technical scientists turning into state employees (army officers) and understanding imported technology. Technical needs of the private sector did not exist for the official policies. It was natural for the technical reality of Greece to affect the structure and organization of technical education; and it was also natural for broader policies to aim at a merchant society and economy, failing thus to favor a broader dissemination of Mathematics.

\section{References}

[1] Alder Ken, 1999. Engineering the Revolution. Arms and Enlightenment in France, 1763-1815. Princeton University Press, Princeton, New Jersey.

[2] Anargyros A, (Avápyopos A.), 1852-1853. Algebra Courses,

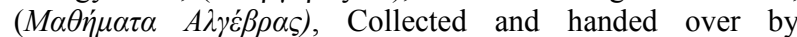
Lieutenant Infantry A. Anargyros during the Scholastic year 1852-1853, the second lithographed, Royal Military School of the Guards, from Royal Lithography, Athens.

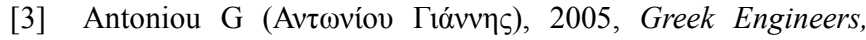
Institutions and Ideas 1900-1940, unpublished PhD, National Technical University of Athens, Athens.

[4] Barnard, H. 1862, Military Schools and Courses of Instruction in the Science and the Art of War, Part 2, Lippincott, Philadelphia.

[5] Bourdon L. P. M., 1821. Eléments d'arithmétique. Paris:

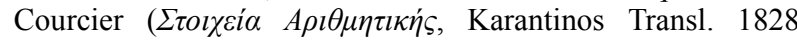
Vienna: Anton Haykul).

[6] Bourdon, L. P. M., 1823. Eléments d'algèbre. Troisième édition, Bachelier, Paris.

[7] Bournazos A. K (Bovpvá̧os A. K) "The founding of the Polytechnic" The centenary of the National. M. Polytechniou, Technical Chronicles, July 1, 1939, No. 181.

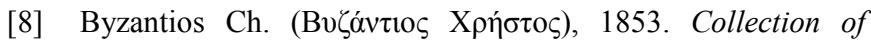
Military Laws and Orders. From 1821 to 1853, Part A, Administrative, vol. A, Royal Printing House, Athens.

[9] Glas Eduard, 2002. «Socially conditioned mathematical change: the case of the France Revolution» Studies in History of Science 33, (709-728).

[10] Heideck, K. 1900, 1901, The Bavarian Philhellenes in Greece during the years 1826-1829: From the memoirs of the Bavarian lieutenant general Charles Baron Heideck. Harmony Vol 1 (1900), Vol 2 (1901). Athens.

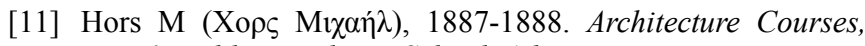
Part 1 Building, Military School, Athens.

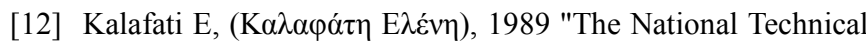
University of Athens at the turn of the century", University: Ideology and Education, IAEN, 19 167-183.

[13] Kapodistrias, I. A. 1841, Letters of IA Kapodistrias to the Governor of Greece. Diplomatic, administrative and private, registered from April 8, 1827 to September 26, 1831. 4 Vol Athens: Ralli.

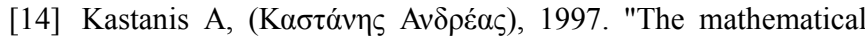
book during the period 1828-1932", Tribute to Antonis Antonakopoulos, edited by K. Aroni-Tsichlis, Papazisis, (531546).

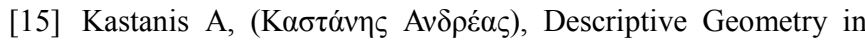
the Greek Military and Technical Education during the 19th Century, Journal of Applied Mathematics \& Bioinformatics, vol. 7 , no. 3, 2017, 13-82.

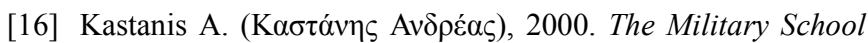
of the Evelpidon during the first years of its operation 18281834, doctoral dissertation, Hellenic Letters, Athens.

[17] Kastanis, Andreas, $1^{\text {st }}$ unpublished monograph, Descriptive Geometry in $19^{\text {th }}$ century Greek education.

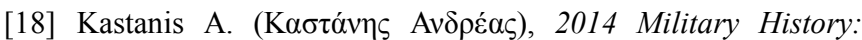
Aspects of the Greek Army. Developments of the 19th century that influenced military operations, Military School, Athens.

[19] Kastanis Andreas, «The teaching of Mathematics in the Greek military academy during the first years of its foundation (1828-1834)» Historia Mathematica, 30 (2003), 123-139.

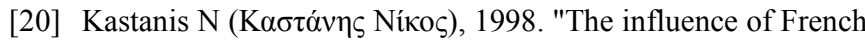
mathematics on modern Greek mathematics education in the period 1800-1804", Aspects of Modern Greek Education, published by Vafiadis Mathematical Library, Thessaloniki, 173-205.

[21] Kastanis, I. and Kastanis, N. 2004. «Transition of Mathematics into Greek education 1800-1840: From Individual choices to institutional framework» (Technical Report No 11, October, Department of Mathematics, Aristotle University of Thessaloniki).

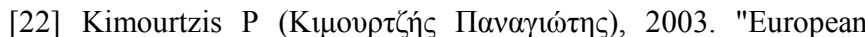
universities as models: The Greek case (1837)", Nefsi, 12, 129-150.

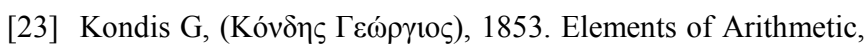
Vlastos, Athens.

[24] Legendre, A. M. 1823 Eléments de Géométrie 12 ed. Paris:

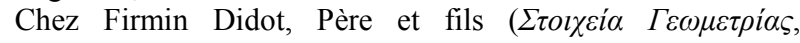
translated by Ioannis Karantinos (1828, 1 ed), (1840, 2 ed) Vol

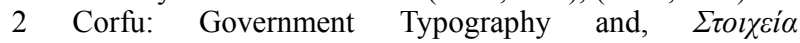

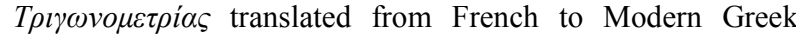
dialect by Dr. Ioannis Karantinos from Kefallinia 1830, vol 6 Corfu: Government Typography.

[25] Legendre, A. M. 1823. Eléments de Géométrie, $12^{\text {th }}$ edition, pub.: Chez Firmin Didot, Père et fils, Paris.

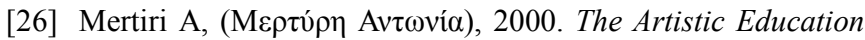
of Young People in Greece (1836-1945), Historical Archive of Greek Youth (IAEN), Athens.

[27] Monge, G., 1811. Géométrie descriptive, pub. Klostermann, Paris.

[28] Neuerer Karl, 1978. Das höhere Lehramt in Bayern im 19. Jahrhundert, Duncker \& Humblot, Berlin.

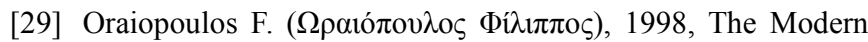
Greek discourse on Architecture and the city. The spatial model of the East, Estia, Athens. 


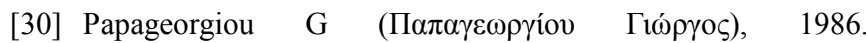
Apprenticeship in the professions, (16th - 20th century), IAEN, Athens.

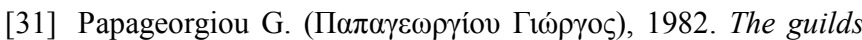
in Ioannina during the 19th and the beginning of the 20th century, doctoral dissertation, University of Ioannina, Ioannina.

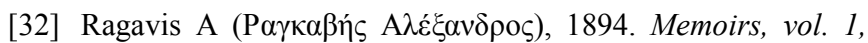
Athens.

[33] Shubring Gr, 1996. «Changing culture and epistemological view on Mathematics and different institutional contexts in $19^{\text {th }}$ century Europe», Mathematical Europe, Goldstein, C et al. (ed), Éditions de la Maison des Sciences de l'homme, Paris. 363-388.

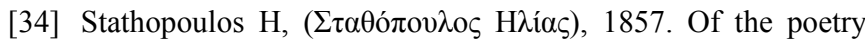
competition of 1857 . The episodes of a logical Arithmetic or criticism, Io Angelopoulos, Athens.

[35] Thiersch Frédéric, 1833. De l' État actuel de la Grèce, F. A Brockhaus, Leipzig, (The Greece of Kapodistrias translation A. Spiliou, Tolidis, 1972 Athens),

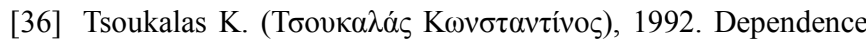
and reproduction. The social role of educational mechanisms in Greece (1830-1922), in edition, Themelio, Athens.

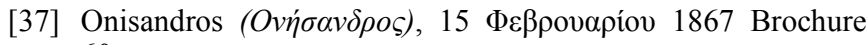
60.

[38] Military Herald Stratiotikos Aggelos 1846. Defending the rights of the army and teaching martial arts, Athens. General National Archives (GAK) Ottonian Archive GAK, The organizational plan of Evelpidon Military School.
[39] 17 March 1842, folder 372: Minutes of the Student Council concerning the distribution of subject matter into six years of study.

[40] 16 March 1853, folder 375, document 038: Professors Payroll GAK, Library of Evelpidon Military School.

[41] 27 June 1848., folder 413, document 017: This document refers to the textbooks used at the Evelpidon.

[42] 23 May 1852, folder 414, document 094: Acquisition of textbooks.

[43] 28 April 1862, folder 414, document 178: Deletion of textbooks due to misplacement. GAK Examinations.

[44] No date 1848, folder 424, documents 151 and 168: Answers to the same test by two different cadets.

[45] No date 1850, folder 409, document 059: Written Geometry examination of 1850 .

[46] 8 September 1855, folder 427, documents 283 and 285: Answers to an examination question by two different cadets.

[47] No date 1854. Folder 427, documents 070 and 071: Examinations of two cadets. Each examination contained only one question.

[48] 11 October 1854. Folder 427: Examination of one cadet.

[49] 12 October, 1854. Folder 427 document 072: Written examination on Differential Calculus.

[50] 12 October, 1854. Folder 427 document 076: Written examination on Differential Calculus. 